УДК 620.2: 330.133.2

М. Г. МАРТОСЕНКО, Л. В. БЕРЛІНОВА

Полтавський науково-дослідний експертно-криміналістичний центр

Міністерства внутрішніх справ Украӥни

\title{
ТОВАРОЗНАВЧА ЕКСПЕРТИЗА АКУМУЛЯТОРНОЇ БАТАРЕЇ
}

\author{
М. Г. МАРТОСЕНКО, Л. В. БЕРЛИНОВА \\ Полтавский научно-исследовательский экспертно-криминалистический центр \\ Министерства внутренних дел Украины
}

\section{ТОВАРОВЕДЧЕСКАЯ ЭКСПЕРТИЗА АККУМУЛЯТОРНОЙ БАТАРЕИ}

\author{
M. MARTOSENKO, L. BERLINOVA \\ Poltava Scientific Research Forensic Centre \\ Ministry of Interior of Ukraine
}

\section{COMMODITY EXAMINATION OF STORAGE BATTERIES}

\author{
https://doi.org/10.36910/6775-2310-5283-2019-12-18
}

\begin{abstract}
Мета. Дослідження теоретичних основ проведення товарознавчих експертиз з метою визначення ринкової вартості обладнання як елементу рухомого майна, зокрема розкрито алгоритм визначення ринкової вартості акумуляторної батареї торгової марки «Sonnenschein» моделі «SOLAR» типу «S12/85A» за допомогою витратного підходу.

Методика. Для визначення ринкової вартості акумуляторної батареї торгової марки «Sonnenschein» моделі «SOLAR» типу «S12/85A» було використано загальноприйняті методи дослідження, зокрема дедуктивний - при теоретичному узагальнення проблеми, монографічний - для детальної конкретизачії наукових засад оцінки ринкової вартості об'єкта дослідження, індуктивний - при формуванні висновку.

Результати. Розглянуто теоретичні основи оцінки обладнання як елементу рухомого майна. У статті розкрито поняття оцінки майна та визначено підходи, щзо застосовують під час проведення товарознавчої експертизи. Охарактеризовано методичні підходи (порівняльний, витратний, дохідний) до оичнки машин та обладнання. Встановлено щзо кожен із зазначений підходів реалізується за допомогою специфічних методик, які залежать від об'єкта оиінки. Обірунтовано доиільність застосування витратного підходу під час проведення товарознавчої експертизи із визначенням ринкової вартості акумуляторної батареї. Проаналізовано механізм проведення товарознавчого дослідження для визначення ринкової вартості акумуляторної батареї. У статті обтрунтовано алгоритм визначення ринкової вартості акумуляторної батареї торгової марки «Sonnenschein» моделі «SOLAR» muny «S12/85A» nid час проведення судовотоварознавчої експертизи, який передбачав: ідентифікацію об'єкта очінки; підбір об 'єкта відтворення (заміщення); визначення вартості відтворення (заміщення) нового об'єкта; визначення характеристик, які підлягають коригуванню; внесення поправок; визначення фізичного зносу; визначення накопиченого зносу; визначення залишкової вартості відтворення (заміщення) об'єкта очінки. Представлено приклад визначення ринкової вартості акумуляторної батареї за допомогою витратного підходу, яким встановлено, що ринкова вартість акумуляторної батареї торгової марки «Sоnпеnschein» моделі
\end{abstract}


«SOLAR» типу «S12/85A» станом на момент проведення експертизи може становити 7393,08 грн.

Практична значимість. Запропонований та апробований алгоритм визначення ринкової вартості акумуляторних батарей може бути використано під час проведення подібних судово-товарознавчих експертиз. Матеріали та напрацювання статті можуть бути використані фахівиями експертних організацій для врахування в роботі під час проведення товарознавчих експертиз.

Ключові слова: машини та обладнання, товарознавча експертиза, оцінка обладнання, ринкова вартість, знос обладнання, порівняльний підхід, витратний підхід, дохідний підхід.

Постановка проблеми у загальному вигляді та її зв'язок із важливими науковими чи практичними завданнями. Розкриття i розслідування злочинів у господарському, цивільному та кримінальному судочинстві вимагає використання сучасних спеціальних знань 3 різних галузей науки і техніки. Практика відображає розвиток загальної теорії судової експертизи, появі нових наукових напрямів, а також сприяє модернізації традиційних розділів судових експертиз. Експертиза є способом збору доказів, тобто фактичних даних, які мають істотне значення для кримінального провадження. На стадії досудового розслідування саме товарознавча експертиза одним із способів доказування та сприяє об’єктивності, повноті та всебічності пізнання події і обставин кримінального правопорушення.

У рамках судової товарознавчої експертизи вирішуються питання: визначення вартості машин, обладнання, сировини та споживчих товарів; встановлення належності товарів до класифікаційних категорій; встановлення ідентифікаційного походження за результатами якого досліджувані товари можуть бути однозначно віднесені до певного загальноприйнятого класу із заздалегідь визначеним комплексом властивостей; визначення змін показників якості товарної продукції; визначення відповідності упакування і транспортування, умов і термінів зберігання товарної продукції до вимог чинних нормативно-правових актів та/або нормативних документів.

Одним із видів товарознавчих досліджень, яке виділене окремою ланкою та має певні особливості його проведення, $\epsilon$ дослідження 3 визначення вартості машин, обладнання, сировини та споживчих товарів. При цьому, розвиток сучасних ринкових відносин у вітчизняній економіці породжує ряд нових теоретичних і практичних проблем, важливе місце серед яких займає проблема оцінки рухомого майна, що стало об’єктом кримінального провадження. 
Відповідно до положень п. 3 Національного стандарту № 1 «Загальна оцінка майна і майнових прав» [1]: «рухоме майно - матеріальні об'єкти, які можуть бути переміщеними без заподіяння їм шкоди. До рухомого майна належить майно у матеріальній формі, яке не є нерухомістю». 3 науковотехнічної точки зору до машин і обладнання відносяться пристрої, що перетворюють енергію, матеріали й інформацію; а з економічної точки зору машинами й обладнанням вважаються всі види активної частини основних фондів, що безпосередньо впливають на предмет праці, тобто силові та робочі машини й обладнання, транспортні засоби, виробничий i господарський інвентар $[2,3]$. Крім того, обладнання, як об'єкт оцінки має вартість тільки тоді, коли воно корисно споживачеві для реалізації його потреб у здійсненні виробничого процесу і в силу цієї причини споживач готовий платити за його придбання. Чим вище ступінь корисності, тим більшу вигоду отримує споживач від володіння даним об'єктом i, відповідно, тим вище вартість. Таким чином, оцінка рухомого майна, зазвичай, має особливості не лише порівняно з іншими об'єктами, але й між окремими видами рухомого майна.

Аналіз останніх досліджень, у яких започатковано вирішення проблеми. Дослідженню особливостей оцінки товарів і визначення їх вартості в умовах ринкових відносин присвятили свої праці відомі українські та закордонні вчені. Заслуговують на увагу останні публікації щодо вирішення проблем, які виникають в практиці судових товарознавчих експертиз машин, обладнання, сировини та споживчих товарів В. В. Архіпова, Т. В. Калінеску, О. С. Донцова, О. О. Михальського, I. А. Петрової, Г. І. Брусенської, Т. А. Кунділовської, С. А. Вілкової. Окремо, у наукових та методичних працях вчених i практиків оцінці вартості рухомого майна, зокрема машин i обладнання, приділено значну увагу. Серед авторів, що розглядають теоретичні і практичні аспекти оцінки рухомого майна, доцільно відзначити таких вітчизняних науковців та практиків: Я. I. Маркус, I. I. Гохберг, С.П. Сударкіна, а також зарубіжних - В. П. Антонов, А. Н. Асаул, Н. В. Вейг, Т. Г. Касьянено, А. П. Ковальов, В. Ф. Сухомлін, В. М. Шалаєв. Однак, питання визначення вартості обладнання під час проведення товарознавчої експертизи потребують подальшого комплексного дослідження 3 метою встановлення єдиного алгоритму визначення його вартості.

Ціль статті полягає у розгляді теоретичних та методичних основ товарознавчих досліджень із визначення вартості обладнання, зокрема особливостей визначення ринкової вартості акумуляторної батареї за допомогою витратного підходу. 
Об'єктом дослідження $є$ акумуляторна батарея торгової марки «Sonnenschein» модель «SOLAR», яка в 2013 році введена в експлуатацію суб'єктом підприємницької діяльності, який здійснює послуги у сфері добування нафти та природного газу.

Методи дослідження. Для визначення ринкової вартості акумуляторної батареї було використано загальноприйняті економічні методи дослідження, зокрема дедукції - при теоретичному осмисленні проблеми, монографічний для детальної конкретизації наукових засад оцінки ринкової вартості об’єкта дослідження, індукції - при формуванні висновків.

Виклад основного матеріалу дослідження 3 повним обгрунтуванням отриманих наукових результатів. Для отримання кваліфікованих, об'єктивних та повних результатів дослідження стосовно визначення ринкової вартості обладнання експерт повинен дотримуватися певного алгоритму проведення товарознавчого дослідження, яке полягає у вивченні пакету документів на товар; встановленні повних товарних характеристик та товарної приналежності досліджуваного об'єкта; визначення рівня якості і його фактичного стану; аналізу ринку досліджуваного об'єкта в конкретному регіоні в конкретний період часу 3 метою визначення його ринкової ціни; узгодженні результатів аналізування цінових пропозиції та проведенні розрахунків із визначення вартості товару. Практика свідчить: якщо експерти проводять дослідження у визначеній послідовності, керуючись розробленими в теорії й апробованими на практиці рекомендаціями, це багато в чому полегшує проведення товарознавчого дослідження та впливає на якість роботи.

Акумуляторні батареї - це товар, на який завжди $є$ попит, особливо у зв'язку 3 розвитком альтернативної енергетики. Хоч масові відключення електроенергії і залишилися в минулому, деяке пожвавлення в промисловості, будівництві та агропромисловому комплексі викликає постійну потребу в акумуляторах. У ході проведення товарознавчого дослідження з'ясовано, що об'єкт дослідження відноситься до класу промислових товарів народного споживання; групи - устаткування електричне та побутові прилади; підгрупи - батареї та акумулятори [4]; виду - свинцево-кислотна акумуляторна батарея; застосування - для використання в установках перетворення сонячної енергії переважно малої потужності; для застосування в приватному секторі, наприклад, в системах електропостачання заміських котеджів, а також в малопотужних автономних пристроях, таких як паркувальні, розмінні автомати, світлові вуличні табло, телефони екстреного зв'язку; за технологією 
- dryfit (фіксація в пристрої електроліту в желеподібному стані); за торговою маркою - «Sonnenschein»; за моделлю - «SOLAR» [5]; за типом - «S12/85A»; за напругою - $12 \mathrm{~B}$; за номінальною ємністю - 85 Ач; за габаритними розмірами (довжина х ширина х висота) - 353 х 175 х 190 мм; маса - 27,1 кг; термін служби - до 12 років за температури навколишнього середовища $20{ }^{\circ} \mathrm{C}$.

Мета товарознавчої експертизи, визначена ініціатором проведення експертизи - «встановлення ринкової вартості акумуляторної батарей торгової марки «Sonnenschein» модель «SOLAR» типу «S12/85A».

Дата, на яку необхідно визначити вартість об'єкта дослідження, відповідно до запитання поставленого на вирішення експертові - «станом на момент проведення експертизи».

Поняття ринкової вартості визначення в Національному стандарту №1 «Загальні засади оцінки майна і майнових прав» [1]: «вартість, за яку можливе відчуження об'єкта оцінки на ринку подібного майна на дату оцінки за угодою, укладеною між покупцем та продавцем, після проведення відповідного маркетингу за умови, що кожна із сторін діяла із знанням справи, розсудливо і без примусу».

Основними параметрами товарів, що впливають на вартість товарів, є [6]: найменування, тип, марка товару, його індивідуальні ознаки й особливості; сорт, клас товару; призначення товару, можливість його використання за призначенням; показники споживних властивостей товарів; конструкційні особливості, розміри; наявність або відсутність у товару дефектів і пошкоджень; товар новий або такий, що був в експлуатації; для товарів, що були в експлуатації (ступінь зносу; дата виготовлення товару; стан упаковки товару; наявність ознак функціонального зносу товару; наявність і склад документації на товар; інші показники, які здатні вплинути на вартість товару).

Експертне дослідження, виходячи із поставленого ініціатором проведення експертизи запитання, проводиться із застосуванням бази, що відповідає ринковій вартості або неринковим видам вартості [1]. Вибір бази оцінки залежить від мети, 3 якою проводиться експертиза товару, його особливостей, а також нормативних вимог.

Вибір методичного підходу до оцінювання товару залежить від специфіки об'єкта та доступності цінової інформації. Відповідно до п. 14 Національного стандарту № 1 «Загальні засади оцінки майна і майнових прав» [1], визначення ринкової вартості об'єкта оцінки можливе із застосуванням усіх методичних підходів у разі наявності необхідної інформації. 
Відповідно до Національного стандарту № 1 «Загальна оцінка майна i майнових прав» [1]:

«... 38. Для проведення оцінки майна застосовуються такі основні методичні підходи: витратний (майновий для оцінки об'єктів у формі цілісного майнового комплексу та у формі фінансових інтересів); дохідний; порівняльний.

40. Витратний підхід передбачає визначення поточної вартості витрат на відтворення або заміщення об'єкта оцінки з подальшим коригуванням їх на суму зносу (знецінення).

42. Дохідний підхід базується на врахуванні принципів найбільш ефективного використання та очікування, відповідно до яких вартість об'єкта оцінки визначається як поточна вартість очікуваних доходів від найбільш ефективного використання об'єкта оцінки, включаючи дохід від його можливого перепродажу.

47. Порівняльний підхід грунтується на врахуванні принципів заміщення та попиту і пропонування. Порівняльний підхід передбачає аналіз цін продажу та пропонування подібного майна з відповідним коригуванням відмінностей між об'єктами порівняння та об'єктом оцінки».

Для проведення аналізу ринку акумуляторних батарей торгової марки «Sonnenschein» моделі «SOLAR» типу «S12/85A», що можуть розглядатись як подібне майно (вироби, які за своїми споживчими властивостями, товарною характеристикою і показниками якості аналогічні досліджуваному об'єкту), здійснено дослідження інформації мережі Інтернет про пропонування до продажу. За результатами проведеного аналізу було встановлено, що на ринку вторинного майна відсутні цінові пропозиції на об'єкти схожі за технічними характеристиками, конструкцією, використаними матеріалами і технологією виробництва із подібним станом та ступенем фізичного зносу досліджуваному об'єкту. Тому під час проведення розрахунків, порівняльний підхід не може бути використано, оскільки цей підхід грунтується на аналізі цін продажу (пропозиції) подібного майна, a інформація щодо продажу подібних акумуляторних батарей, станом на момент проведення експертизи, відсутня. Дохідний підхід не можна застосувати через відсутність відомостей про фактичні та/або очікуванні доходи від найбільш ефективного використання об'єкта оцінки, включаючи дохід від можливого перепродажу, а також витрати, які здійснить власник.

Ураховуючи викладене, при проведенні дослідження експертом було застосовано витратний методичний підхід, який грунтується на врахуванні 
принципів корисності і заміщення [1]. Основними методами витратного підходу є метод прямого відтворення та метод заміщення. Метод прямого відтворення полягає у визначенні вартості відтворення 3 подальшим вирахуванням суми зносу (знецінення). Метод заміщення полягає у визначенні вартості заміщення 3 подальшим вирахуванням суми зносу (знецінення). За допомогою методів прямого відтворення та заміщення визначається залишкова вартість заміщення (відтворення) [1], оскільки при цьому визначається скільки може коштувати об'єкт, якщо його створили і продали сьогодні, тобто в існуючих ринкових умовах і при рівні цін, що діє.

Алгоритм визначення ринкової вартості за допомогою витратного підходу передбачає [7]:

- ідентифікацію об'єкта оцінки; підбір об’єкта відтворення (заміщення);

- $\quad$ визначення вартості відтворення (заміщення) нового об'єкта;

- $\quad$ визначення характеристик, які підлягають коригуванню;

- внесення поправок; визначення фізичного зносу;

- визначення функціонального зносу;

- визначення економічного зносу;

- визначення накопиченого зносу;

- визначення залишкової вартості відтворення (заміщення) об’єкта оцінки.

Витратний підхід визначає поточну вартість об’єкта дослідження шляхом розрахунку вартості заміщення (відтворення) 3 урахуванням знецінення, викликаного виявленими елементами зносу. Вартість заміщення (відтворення) - це витрати на відтворення в сучасних умовах точної копії об'єкту 3 використанням аналогічних матеріалів і збереженням всіх експлуатаційних параметрів, а також з урахуванням всіх присутніх в нім переваг і недоліків [7].

При визначення ринкової вартості акумуляторної батареї торгової марки «Sonnenschein» моделі «SOLAR» типу «S12/85A» за допомогою витратного підходу використано розрахунок накопиченого зносу і залишкової вартості заміщення за підходом Гохберга I. I. [7].

Накопичений знос розраховується за методом строку життя обладнання, який базується на обгрунтованому припущенні про залишковий строк економічного життя, при цьому всі наявні види зносу об'єкта оцінки вважаються повністю врахованими [7]. За своєю природою строк економічного життя об'єкта оцінки наближений до нормативного (розрахункового) строку життя, на базі якого встановлюються норми 
амортизації і періодичності ремонтного обслуговування. Ефективний вік - це час, яким оцінюється тривалість життя об'єкта виходячи 3 його фізичного стану, при цьому ефективний вік може дорівнювати, бути меншим або більшим за фактичний вік, залежно від умов експлуатації обладнання [7].

Розрахунок накопиченого зносу проведено за формулою, за умови що ефективний вік об'єкта менший або дорівнює його хронологічному віку (1):

$$
3_{\mathrm{H}}=\frac{\mathrm{T}_{x}}{\mathrm{~T}_{\mathrm{X}}+\mathrm{T}_{3}} \cdot 100 \%
$$

де 3 Н - накопичений знос $(\%)$;

$\mathrm{T}_{\mathrm{X}}$ - хронологічний вік об'єкта;

$\mathrm{T}_{3}$ - залишковий строк економічного життя об'єкта.

У розрахунках накопиченого зносу використані наведені нижче формули. Розрахунок залишкової вартості заміщення проведено за формулою (2):

$$
\mathrm{B}_{\mathrm{P}}=\mathrm{B}_{\text {ДЗ }}-\mathrm{H}_{\text {В3 }}-\mathrm{B}_{\text {РД}},
$$

де $\mathrm{B}_{\text {дз }}$ - вартість заміщення об'єкта оцінки в грн.;

$\mathrm{H}_{\mathrm{B} 3}-$ накопичений знос у вартісному вигляді в грн.;

В Рд - вартість робіт по демонтажу в грн.

Ефективний вік об'єкта визначено за формулою (3):

$$
\mathrm{T}_{\mathrm{E}}=\mathrm{T}_{\mathrm{H}} \cdot \frac{3_{\Phi I 3}}{100},
$$

де $\mathrm{T}_{\mathrm{E}}$ - ефективний вік об'єкта;

$\mathrm{T}_{\mathrm{H}}$ - загальний (нормативний) строк економічного життя активу;

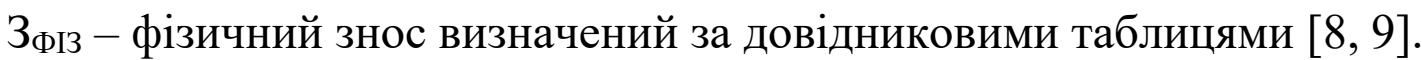

Залишковий строк економічного життя визначений за умови поточного стану додаткових значних капіталовкладень за формулою (4):

$$
\mathrm{T}_{3}=\mathrm{T}_{\mathrm{H}}-\mathrm{T}_{\mathrm{E}},
$$

де $\mathrm{T}_{3}$ - залишковий строк економічного життя об'єкта;

$\mathrm{T}_{\mathrm{H}}-$ загальний (нормативний) строк економічного життя активу;

$\mathrm{T}_{\mathrm{E}}$ - ефективний вік об'єкта.

Для визначення залишкової вартості (відтворення) заміщення використано розрахунок накопиченого зносу методом строку життя (табл. 1 та табл. 2). 
Таблиця 1

Розрахунок накопиченого зносу акумуляторної батареї торгової марки «Sonnenschein» моделі «SOLAR» типу «S12/85A»

\begin{tabular}{|l|c|l|}
\hline \multicolumn{1}{|c|}{ Показник } & Значення & \multicolumn{1}{|c|}{ Обгрунтування } \\
\hline Рік випуску & 2013 & $\begin{array}{l}\text { відповідно до матеріалів } \\
\text { кримінального провадження }\end{array}$ \\
\hline Фізичний знос, \% & 35 & оціночна шкала фізичного зносу [7, 8] \\
\hline $\begin{array}{l}\text { Загальний (нормативний) строк } \\
\text { економічного життя, років }\end{array}$ & 12 & інформації з мережі Інтернет [5] \\
\hline Хронологічний вік, років & 5,7 & 3 01.06.2013 по 30.01.2019 \\
\hline Ефективний вік, років & 4,2 & $=12 \times 35 \%$ \\
\hline $\begin{array}{l}\text { Залишковий строк економічного } \\
\text { життя активу, років }\end{array}$ & 7,8 & $=12-4,2$ \\
\hline Накопичений знос, \% & 42,2 & Розрахунок за формулою 1 \\
\hline
\end{tabular}

Таблиця 2

Розрахунок залишкової вартості заміщення (відтворення) акумуляторної батареї торгової марки «Sonnenschein» моделі «SOLAR» типу «S12/85A»

\begin{tabular}{|l|c|l|}
\hline \multicolumn{1}{|c|}{ Показник } & Значення & \multicolumn{1}{c|}{ Обгрунтування } \\
\hline Вартість заміщення, грн. & 12790,80 & Цінова інформація мережі Інтернет [5] \\
\hline Накопичений знос, \% & 42,2 & Таблиця 1 \\
\hline Накопичений знос, грн. & 5397,72 & $=12790,80$ х 42,2\% \\
\hline $\begin{array}{l}\text { Залишкова вартість заміщення } \\
\text { (відтворення), грн. }\end{array}$ & 7393,08 & $=12790,80-5397,72$ \\
\hline
\end{tabular}

Відповідно до положень п. 22 Національного стандарту № 1 «Загальна оцінка майна і майнових прав» [1]: «... Залишкова вартість заміщення (відтворення) як база оцінки визначається із застосуванням витратного підходу і використовується для проведення оцінки спеціалізованого майна, у тому числі для ведення бухгалтерського обліку з метою визначення його справедливої вартості згідно з положеннями (стандартами) бухгалтерського обліку. Якщо умови угод щодо спеціалізованого майна, для укладання яких проводиться оцінка, відповідають вимогам, що висуваються для визначення ринкової вартості, залишкова вартість заміщення (відтворення) може дорівнювати їх ринковій вартості».

Залишкова вартість заміщення (відтворення) об’єкта дослідження «акумуляторної батарей торгової марки «Sonnenschein» моделі «SOLAR» типу «S12/85A» враховує особливості спеціалізованого майна: загальний стан, вузьке цільове призначення для комплектування установок резервного 
живлення в системах електропостачання, найбільшу корисність та цінність у складі цілісного майнового комплексу. Отже, за результатами проведених розрахунків, відповідно до п. 22 Національного стандарту № 1 «Загальна оцінка майна і майнових прав» визначена залишкова вартість (заміщення) відтворення дорівнює ринковій вартості об'єкта дослідження.

Ринкова вартість акумуляторної батареї торгової марки «Sonnenschein» моделі «SOLAR» типу «S12/85A» станом на момент проведення експертизи може становити 7393,08 грн.

Висновки та перспективи подалыших досліджень. У ході проведення товарознавчої експертизи була визначена ринкова вартість акумуляторної батареї торгової марки «Sonnenschein» моделі «SOLAR» типу «S12/85A» за допомогою витратного підходу. Перспективи подальших досліджень у даному напрямі будуть спрямовані на розробку методики експертної оцінки машин i обладнання при проведенні судово-товарознавчих експертиз в структурі Експертної служби МВС України.

\section{Список використаних джерел:}

1. Національний стандарт № 1 «Загальні засади оцінки майна і майнових прав»: затверджений Постановою Кабінету Міністрів України від 10.09.2003 р. № 1440 (редакція від 15.04.2015 р.) [Електронний ресурс]: База даних «Законодавство України»// Верхова Рада України. Режим доступу: http://zakon0.rada.gov.ua/laws/show/1440-2003-\%D0\%BF.

2. Краснокутська Н.С. Потенціал підприємства: формування та оцінка: навчальний посібник. - К.: Центр навчальної літератури, 2005. - 352 с.

3. Оценка рыночной стоимости машин и оборудования: учебное пособие; авторский коллектив, общая редакция О. С. Назаров, Э. А.Третьяков - М.: Международная академия оценки и консалтинга, 2003. - 134 с.

4. Державний класифікатор продукції та послуг: ДК 016:2010: прийнято та надано чинності Наказом Держспоживстандарту України від 11.10.2010 p. № 457 (редакція від 01.03.2017 р.) [Електронний ресурс]: База даних «Законодавство України» // Верхова Рада України. Режим доступу: https://zakon.rada.gov.ua/rada/show/v457a609-10\#n184.

5. Аккумуляторная батарея Sonnenschein S12/85A // Энергоэффективные технологии, проверенные временем [Електронний ресурс]: Офіційний сайт приватного підприємства «Аванте». Режим доступу: https://avante.com.ua/catalog/akkumuljatornaja_batareja_sonnenschein_s12_85_a-02501/.

6. Вилкова С. А. Товароведческие экспертизы: теория и практика: учебное пособие. - Энгельс. 1999. - 122 с.

7. Гохберг I. І. Оцінка машин і обладнання: навчально-практичний посібник / Ігор Ісаакович Гохбер; за наук. ред. канд. екон. наук, доц. М.Л. Лапішко; Українське товариство оцінювачів. - Київ, 2014. - 352 с.

8. Оценка стоимости машин и оборудования: учебное пособие/ под общей редакцией В. П. Антонова. - М.: Издательский Дом «Русская оценка», 2005. - 254 с. 
Цель. Исследование теоретических основ проведения товароведческой экспертизы с целью определения рыночной стоимости оборудования как элемента движсмого имущества, в том числе раскрыто алгоритм определения рыночной стоимости аккумуляторной батареи торговой марки «Sonnenschein» модели «SOLAR» типа «S12 / 85А» с помошью затратного подхода.

Методика. Для определения рыночной стоимости аккумуляторной батареи торговой марки «Sonnenschein» модели «SOLAR» типа «S12 / 85A» были использовань общепринятые методы исследования, в частности дедуктивный - при теоретическом обобщения проблемы, монографический - для детальной конкретизачии научных основ оценки рыночной стоимости объекта исследования, индуктивный - при формировании заключения.

Результаты. Рассмотрены теоретические основы оценки оборудования как элемента движимого имущества, В статье раскрыто понятие оценки имущества и определены подходы, применяемые при проведении товароведческой экспертизы. Охарактеризованы методические подходы (сравнительный, затратный, доходньій) $к$ оиенке машин и оборудования. Установлено, что каждый из указанных подходов реализуется с помощью специфических методик, которые зависят от объекта оценки. Обоснована иелесообразность применения затратного подхода при проведении товароведческой экспертизы с определением рыночной стоимости аккумуляторной батареи. Проанализирован механизм проведения товароведческого исследования для определения рыночной стоимости аккумуляторной батареи. $B$ статье обоснован алгоритм определения рыночной стоимости аккумуляторной батареи торговой марки «Sonnenschein» модели «SOLAR» типа «S12/85A» при проведении судебно-товароведческой экспертизы, который предусматривал: идентификаиию объекта оценки; подбор объекта воссоздания (замещения); определение стоимости воссоздания (замещения) нового объекта; определение характеристик, подлежащих корректировке; внесения поправок; определения физического износа; определения накопленного износа; определения остаточной стоимости воссоздания (замещения) объекта оченки. Представлен пример определения рыночной стоимости аккумуляторной батареи с помощью затратного подхода, которым установлено, что рыночная стоимость аккумуляторной батареи торговой марки «Sonnenschein» модели «SOLAR» типа «S12/85A» на момент проведения экспертизы может составлять 7393,08 грн.

Практическая значимость. Предложенный $u$ апробированный алгоритм определения рыночной стоимости аккумуляторных батарей может быть использован при проведении подобных судебно-товароведческая экспертиза. Материаль и наработки статьи могут быть использованы специалистами экспертных организаций для использования в работе при проведении товароведческих экспертиз.

Ключевые слова: машины и оборудование, товароведческая экспертиза, оценка оборудования, рыночная стоимость, износ оборудования, сравнительный подход, затратный подход, доходный подход.

Purpose. The research of the theoretical foundations of commodity expertise of determination of the equipment's value as an element of movable property, in particular, the algorithm for determining the market value of a storage battery brand «Sonnenschein» model «SOLAR» type «S12/85A» with the help of a cost approach is disclosed.

Methodology. In order to determine the market value of the storage battery brand «Sonnenschein» model «SOLAR» type «S12/85A», common methods of research were used, in particular deduction method - in the theoretical generalization of the problem, monographic 
method - for the detailed concretization of the scientific basis for assessing the market value of the object of research, induction method-making the conclusion.

Findings. In this work theoretical background of evaluation of equipment as the element of movables. In article, the concept of an assessment of property is opened and the approaches applied when carrying out merchandising examination are defined. Methodological approaches to machinery and equipment evaluation such as comparative, cost based, income based are characterized. It is established that each of the specified approaches is realized by means of specific techniques, which depend on object of the assessment. Expediency of application of expense approach during conducting commodity expertise with determination of market value of the storage battery was proved. The mechanism of conducting commodity research with the purpose of determining the market value of equipment is analyzed. The article substantiates the algorithm for determining the market value of a storage battery brand «Sonnenschein» model «SOLAR» type «S12/85A» during a judicial-commodity expertise, which provided: identification of an object of assessment; selection of a subject to reproduction (replacement) determination of cost of reproduction (replacement) of a new object; definition of the characteristics which are subject of adjustment; amending; determination of physical wear; determination of the saved-up wear; determination of residual cost of reproduction (replacement) of an object of assessment. An example of the definition of the market value of a storage battery by an expense approach was presented. It was established that the market value of the storage battery brand "Sonnenschein» model «SOLAR» type «S12/85A» for the time of the examination can be 7393,08 UAH.

The practical value. The proposed and tested algorithm of determining the market value of storage batteries can be used during judicial-commodity expertise's. Materials and practices of article can be used by specialists of the expert organizations for using in work while carrying out commodity expertise.

Keywords: machinery and equipment, commodity expertise, equipment evaluation, market value, comparative methodology, cost based methodology, income based methodology.

Стаття рекомендована до публікаиії доктором технічних наук, професором ПУЕТ Кожушком В.Г. Дата надходження в редакиію 19.02.2019 р. 